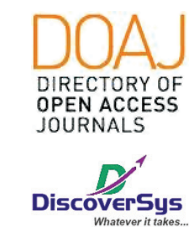

Published by DiscoverSys

\title{
Uji daya hambat sediaan tetes telinga ekstrak daun "Tebel-Tebel" (Hoya carnosa) terhadap bakteri gram positif dan gram negatif penyebab Otitis Media Supuratif Kronik (OMSK) aktif tipe benigna secara in-vitro di RSUP Sanglah, Bali, Indonesia
}

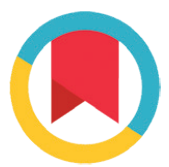

CrossMark

\author{
I Wayan Lolik Lesmana, ${ }^{1{ }^{*}}$ Eka Putra Setiawan, ${ }^{1}$ I Made Jawi ${ }^{2}$
}

\section{ABSTRACT}

Background: The recent Chronic Suppurative Otitis Media (CSOM) management by antibiotic Chloramphenicol 1\% ear drop seems to be ineffective due to the bacterial resistance, ototoxic effects, and the idiosyncratic response. Traditional medicine from Hoya carnosa leaf as ear drops has been suggested for alternative medicine because of its antibacterial properties. This study aims to evaluate the inhibition test of Hoya carnosa leaf-extract towards gram-positive and gram-negative bacteria cause.

Methods: An experimental study with a completely randomized post-test control group design has been conducted to the American Type Culture Collection (ATCC), which consists of Staphylococcus aureus, Streptococcus pyogenes, Pseudomonas aeruginosa dan Enterobacter spp. The Hoya carnosa leaf extract in-ear drop emulsion has been divided into 3 concentrations, such as $1 \%, 3 \%$, and $5 \% \mathrm{w} / \mathrm{v}$ by simple random technique. As a positive control used Chloramphenicol 1\% and as a negative control using $96 \%$ ethanol. Each treatment was repeated 5 times and data were analyzed by SPSS version 17 for Windows.

Results: There was a significant difference in inhibitory diameter (IH) from ear drop dosage of (Hoya carnosa) leaf emulsions to Streptococcus pyogenes bacteria in concentrations of 3\% and $5 \%$ $(p<0.05)$. There was a significant difference from the inhibitory drug resistance (DDH) ear drop emulsion preparation leaf extract "tebel-tebel" (Hoya carnosa) concentrations of 1\%, 3\% and 5\% with Cholrampenicol 1\% against Streptococcus pyogenes bacteria $(p<0.05)$.

Conclusion: There was a significant difference in inhibitory diameter (DDH) and inhibitory drug resistance from Hoya carnosa leaf emulsions ear drops to Streptococcus pyogenes bacteria.

Keywords: Hoya carnosa, Ear Drop, Antibacterial, Inhibitory Diameter.

Cite This Article: Lesmana, I.W.L., Setiawan, E.P., Jawi, I.M. 2020. Uji daya hambat sediaan tetes telinga ekstrak daun "Tebel-Tebel" (Hoya carnosa) terhadap bakteri gram positif dan gram negatif penyebab Otitis Media Supuratif Kronik (OMSK) aktif tipe benigna secara in-vitro di RSUP Sanglah, Bali, Indonesia. Intisari Sains Medis 11(2): 652-657. D0I: 10.15562/ism.v11i2.805

\section{ABSTRAK}

Latar Belakang: Penatalaksanaan Otitis Media Supuratif Kronis (OMSK) saat ini dengan antibiotik Kloramfenikol tetes telinga 1\% tampaknya tidak efektif karena adanya resistensi bakteri, efek ototoksik, dan respon idiosinkratik. Obat tradisional dari daun Hoya carnosa sebagai obat tetes telinga telah disarankan untuk pengobatan alternatif karena sifat antibakterinya. Penelitian ini bertujuan untuk mengevaluasi uji daya hambat ekstrak daun Hoya carnosa terhadap bakteri penyebab gram positif dan gram negatif.

Metode: Telah dilakukan penelitian eksperimental dengan rancangan acak kelompok kontrol post-test pada American Type Culture Collection (ATCC) yang terdiri dari Staphylococcus aureus, Streptococcus pyogenes, Pseudomonas aeruginosa dan Enterobacter spp. Ekstrak daun Hoya carnosa dalam emulsi tetes telinga dibagi menjadi 3 konsentrasi yaitu
1\%, 3\% dan 5\% b / v dengan teknik acak sederhana. Sebagai kontrol positif digunakan Kloramfenikol $1 \%$ dan sebagai kontrol negatif menggunakan etanol 96\%. Tiap perlakuan diulang sebanyak 5 kali dan data dianalisis dengan SPSS versi 17 untuk Windows.

Hasil: Terdapat perbedaan bermakna dalam uji diameter daya hambat (DDH) antara dosis tetes telinga emulsi daun Hoya carnosa terhadap bakteri Streptococcus pyogenes pada konsentrasi 3\% dan 5\% ( $p<0,05)$. Ada perbedaan yang bermakna antara ekstrak daun "tebel-tebel" (Hoya carnosa) sediaan emulsi tetes telinga konsentrasi 1\%,3\% dan 5\% dengan Cholrampenicol $1 \%$ terhadap bakteri Streptococcus pyogenes $(p<0,05)$. Kesimpulan: Ada perbedaan yang bermakna pada diameter hambat (DDH) dan resistensi obat penghambat emulsi daun Hoya carnosa tetes telinga terhadap bakteri Streptococcus pyogenes.
IImu Kesehatan THT-KL, Fakultas

Kedokteran, Universitas Udayana,

RSUP Sanglah, Bali, Indonesia;

loliklesmana22@gmail.com

Diterima: 02-05-2019

Disetujui: 25-07-2020

Diterbitkan: 01-08-2020
Kata kunci: Hoya carnosa, Tetes Telinga, Antibakteri, Diameter Daya Hambat

Cite Pasal Ini: Lesmana, I.W.L., Setiawan, E.P., Jawi, I.M. 2020. Uji daya hambat sediaan tetes telinga ekstrak daun "Tebel-Tebel" (Hoya carnosa) terhadap bakteri gram positif dan gram negatif penyebab Otitis Media Supuratif Kronik (OMSK) aktif tipe benigna secara in-vitro di RSUP Sanglah, Bali, Indonesia. Intisari Sains Medis 11(2): 652-657. D0I: 10.15562/ism.v11i2.805 


\section{PENDAHULUAN}

Otitis media supuratif kronis (OMSK) tipe benigna aktif yang di Indonesia dikenal dengan istilah penyakit "congek" dan di Bali dikenal dengan istilah "curek" adalah peradangan kronik telinga tengah dengan perforasi membran timpani dan riwayat keluarnya sekret dari telinga (otorea) lebih dari 2 bulan secara terus-menerus atau hilang timbul., ${ }^{1,2}$ Pada beberapa penelitian dilaporkan bahwa OMSK sering disebabkan oleh bakteri Staphylococcus aureus, Streptococcus pyogenes Pseudomonas aeruginosa, dan Enterobacter spp. ${ }^{1,2}$

Penatalaksanaan OMSK saat ini berdasarkan standar terapi Departemen Kesehatan RI dan Badan Penyelenggara Jaminan Sosial (BPJS) pada tingkat penanganan primer di puskesmas menggunakan antibiotika sediaan topikal tetes telinga Chloramphenicol $1 \%$ berdasarkan studi sebelumnya. ${ }^{3}$ Permasalahan yang timbul saat ini adalah efektifitas Chloramphenicol $1 \%$ mulai berkurang karena resistensi bakteri, efek ototoksik dan terjadinya respon idiosinkrasi yang menyebabkan anemia aplastik fatal, sehingga penggunaannya mulai dibatasi. ${ }^{4}$ Dengan kondisi geografis yang sulit, penyebaran puskesmas tidak merata serta obat tetes telinga untuk telinga tengah pilihan lain seperti Ofloxacin $3 \mathrm{mg}$ yang tersedia di RS rujukan juga sangat terbatas dan relatif mahal, sangat menyulitkan penanganan penderita OMSK terutama di daerah terpencil. ${ }^{5}$ Permasalahan tersebut memerlukan solusi berupa adanya obat alternatif pengganti dengan menggunakan bahan dasar alam yang mudah didapat, tersebar di seluruh wilayah Indonesia dan biaya yang murah, sehingga terjangkau oleh masyarakat miskin.

Indonesia terkenal dengan sumber kekayaan hayati yang melimpah dan banyak dimanfaatkan oleh masyarakat sebagai sumber pangan maupun obat-obatan, salah satunya adalah daun Hoya carnosa. Pemanfaatan daun tumbuhan Hoya sebagai obat secara praktis telah diaplikasikan sebagai obat bisul serta digunakan pengganti suntik insulin pada penderita diabetes pada penelitian sebelumnya. ${ }^{6}$ Pada penelitian pleh Rahayu S et al., ditemukan bahwa senyawa aktif yang terkandung dalam daun tanaman Hoya carnosa yaitu flavanoid, saponin, alkaloid dan tannin memiliki efek anti bakteri. ${ }^{7}$

Penelitian pedahuluan terhadap efektifitas antibakteri ekstrak daun Hoya carnosa pada bakteri Gram positif dan Gram negatif penyebab OMSK telah dilakukan dengan menggunakan ekstrak murni daun Hoya carnos secara in-vitro. ${ }^{7,9}$ Hasil penelitian tersebut adalah resistensi pada konsentrasi ekstrak $80 \%$ dan intermediate pada konsentrasi ekstrak 100\%, baik pada bakteri Gram positif maupun Gram negatif.,

Ekstrak bahan alam berupa daun Hoya carnosa tidak dapat diaplikasikan langsung ke dalam telinga manusia ataupun hewan coba, karena memiliki banyak kelemahan fisik, biologis dan kimia. Ekstrak bahan alam agar dapat diaplikasikan ke dalam telinga hewan coba maupun manusia pada uji in-vivo, uji toksisitas maupun uji klinis selanjutnya harus dibuat sediaan berupa obat tetes telinga dengan standar farmasi dan dilakukan pengujian secara in-vitro untuk menilai efektifitas antibakteri daun Hoya carnosa dalam bentuk sediaan tersebut.

Berkaitan dengan hal tersebut maka penelitian ini bertujuan untuk mengetahui uji daya hambat sediaan tetes telinga ekstrak daun "Tebel-Tebel" (Hoya carnosa) terhadap bakteri gram positif dan gram negatif penyebab Otitis Media Supuratif Kronik (OMSK) aktif tipe benigna secara in-vitro di RSUP Sanglah, Bali, Indonesia.

\section{METODE PENELITIAN}

Penelitian eksperimental ini dilakukan dengan rancangan completely randomized posttest only control group design dengan melakukan pengujian terhadap sediaan emulsi tetes telinga ekstrak daun "tebel-tebel" (Hoya carnosa) di Program Studi Farmasi Fakultas MIPA Universitas Udayana maupun Bagian Mikrobiologi Fakultas Kedokteran UNUD Denpasar pada November 2017-Januari 2018. Populasi target penelitian adalah seluruh media biakan American Type Culture Collection (ATCC) bakteri Gram positif dan Gram negatif penyebab OMSK aktif tipe benigna. Populasi terjangkau adalah media biakan ATCC bakteri Staphylococcus aureus, Streptococcus pyogenes, Pseudomonas aeruginosa dan Enterobacter spp penyebab OMSK aktif tipe benigna dimana berjumlah 20 yang terdiri dari 4 kelompok dengan simple random sampling. Pada masing-masing kelompok terdapat 5 perlakuan dengan tiga tahap konsentrasi yaitu 1\%, 3\% dan 5\% b/v dimana Chloramphenicol $1 \%$ dipergunakan sebagai kontrol positif kontrol negatif menggunakan etanol 96\% yang secara simultan dilakukan dengan 5 kali pengulangan.

Tetes telinga ekstrak daun Hoya carnosa adalah tetes telinga yang terbuat dari ekstak daun "tebeltebel" (Hoya carnosa) yang diproses kimia dengan metode emulsi menjadi sebuah obat tetes telinga oleh bagian Farmasi Fakultas MIPA Universitas Udayana. Uji aktivitas antibakteri yang dimaksudkan pada penelitian ini dalah suatu metode untuk menentukan tingkat kerentanan bakteri terhadap zat antibakteri dan untuk mengetahui senyawa 
murni yang memiliki aktivitas antibakteri, dimana dilihat berdasarkan daya hambat pertumbuhan bakteri yaitu aktivitas zat untuk membentuk zona bening pada media uji sebagai tanda terhambatnya pertumbuhan bakteri. Sedangkan Diameter Daya Hambat (DDH) adalah diameter dimana bakteri tidak tumbuh yang ditandai dengan terbentuknya zona atau daerah bening yang dapat diukur dengan jangka sorong (caliper) dalam satuan milimeter $(\mathrm{mm})$. Zona bening yang diamati merupakan zona diameter daya hambat yang diukur dengan menggunakan jangka sorong. Sebagai parameter zona hambat yang terbentuk pada jam ke-24 setelah pengujian dibandingkan dengan hasil pengukuran pada kontrol positif yaitu Chloramphenicol 1\% tetes telinga. Daerah bening merupakan petunjuk kepekaan baktei terhadap antibiotik atau bahan antibakteri lainnya yang dinyatakan dengan diameter daya hambat (DDH). DDH diukur dengan satuan millimeter $(\mathrm{mm})$. Terdapa beberapa kriteria untuk menginterpretasikan DDH yang menggambarkan potensi antibakteri. Namun dua kriteria umum yang digunakan dalam berbagai penelitian adalah kriteria Davis dan Stout serta kriteria Clinical Laboratory and Standard Institute (CLSI) dengan standar antimikroba agen kontrol positif (Chloramphenicol) ( $>20 \mathrm{~mm}$ : sangat kuat; 11-19 mm: kuat; 5-10 mm: sedang; $<5 \mathrm{~mm}$ : lemah). ${ }^{9}$

Data ditampilkan secara deskriptif dalam bentuk tabel yang memuat data mengenai efektivitas antibakteri sediaan emulsi obat tetes ekstrak daun Hoya carnosa yang telah diujikan pada media agar kuman ATCC dalam konsentrasi 1\%, 3\%, 5\%, etanol 96\% dan Chloramphenicol 1\%. Aktifitas antibakteri dianalisa secara statistik dengan uji One-Sample Kolmogorov-Smirnov untuk mengetahui normalitas dan homogenitas data yang diperoleh dari hasil pengujian. Seluruh data penelitian dianalisis dengan SPSS versi 17 untuk Windows.

\section{HASIL}

Hasil uji antibakteri sediaan emulsi tetes telinga Ekstrak daun "tebel-tebel" (Hoya carnosa) dengan konsentrasi masing-masing $1 \%, 3 \%$ dan $5 \%$ terhadap bakteri seperti Staphylococcus aureus,

Tabel 1 Rerata Diameter Daya Hambat (DDH) Sediaan Emulsi Tetes Telinga Ekstrak Daun Hoya carnosa Terhadap Bakteri Staphylococcus aureus dan Streptococcus pyogenes

\begin{tabular}{lcccc}
\hline Kelompok & Pengulangan & DDH Minimal & DDH Maksimal & I DDH $(\mathbf{m m})$ \\
\hline Staphlococcus aureus & & & & \\
Kontrol Positif & 5 & 30.00 & 33.00 & 31.20 \\
Tetes Telinga 1\% & 5 & 0.00 & 0.00 & 0.00 \\
Tetes Telinga 3\% & 5 & 0.00 & 0.00 & 0.00 \\
Tetes Telinga 5\% & 5 & 0.00 & 0.00 & 0.00 \\
Kontrol negatif & 5 & 0.00 & 0.00 & 0.00 \\
Streptococcus pyogenes & & & & \\
Kontrol Positif & 5 & 29.00 & 31.00 & 30.40 \\
Tetes Telinga 1\% & 5 & 9.00 & 10.00 & 9.80 \\
Tetes Telinga 3\% & 5 & 10.00 & 11.00 & 10.20 \\
Tetes Telinga 5\% & 5 & 7.00 & 8.00 & 7.80 \\
Kontrol negatif & 5 & 0.00 & 0.00 & 0.00 \\
Pseudomonas aeruginosa & & & & \\
Kontrol Positif & 5 & 15.00 & 20.00 & 18.00 \\
Tetes Telinga 1\% & 5 & 0.00 & 0.00 & 0.00 \\
Tetes Telinga 3\% & 5 & 0.00 & 0.00 & 0.00 \\
Tetes Telinga 5\% & 5 & 0.00 & 0.00 & 0.00 \\
Kontrol negatif & 5 & 0.00 & 0.00 & 0.00 \\
Enterobacter spp & & & & \\
Kontrol Positif & 5 & 29.00 & 31.00 & 30.20 \\
Tetes Telinga 1\% & 5 & 0.00 & 0.00 & 0.00 \\
Tetes Telinga 3\% & 5 & 0.00 & 0.00 & 0.00 \\
Tetes Telinga 5\% & 5 & 0.00 & 0.00 & 0.00 \\
Kontrol negatif & 5 & 0.00 & 0.00 & 0.00 \\
\hline
\end{tabular}


Streptococcus pyogenes, Pseudomonas aeruginosa, dan Enterobacter spp ditunjukkan dalam Tabel 1. Hasil pengukuran rerata diameter daya hambat (DDH) sediaan emulsi tetes telinga ekstrak daun Hoya carnosa terhadap bakteri Staphylococcus aureus menunjukkan tidak didapatkan adanya daya hambat di media agar pada konsentrasi tetes telinga $1 \%, 3 \%$ dan $5 \%$, dengan rerata daya hambat adalah $0,00 \mathrm{~mm}$. Rerata daya hambat dari kontrol positif (Chloramphenicol 1\%) adalah 31,20 mm dan rerata kontrol negatif (Etanol 96\%) adalah 0,0 mm (Tabel 1).

Sedangkan pada Streptococcus pyogenes menunjukkan adanya daya hambat yang tampak sebagai zona bening pada media agar. Pada konsentrasi tetes telinga $1 \%$ didapatkan rerata daya hambat 9,8 mm. Konsentrasi tetes telinga 3\% didapatkan rerata daya hambat $10,2 \mathrm{~mm}$ dan pada konsentrasi tetes telinga 5\% didapatkan rerata daya hambat $7,8 \mathrm{~mm}$ dengan. Rerata daya hambat dari kontrol positif (Chloramphenicol 1\%) adalah 30,4 $\mathrm{mm}$ dan rerata kontrol negatif (Etanol 96\%) adalah 0,0 mm (Tabel 1).

Hasil pengukuran rerata diameter daya hambat (DDH) sediaan emulsi tetes telinga ekstrak daun Hoya carnosa terhadap bakteri Pseudomonas aeruginosa menunjukkan tidak terdapat daya hambat di media agar pada konsentrasi tetes telinga 1\%, 3\% dan $5 \%$, dengan rerata daya hambat adalah $0,00 \mathrm{~mm}$ (Tabel 1). Sedangkan hasil pengukuran rerata diameter daya hambat (DDH) sediaan emulsi tetes telinga ekstrak daun Hoya carnosa terhadap bakteri Enterobacter spp menunjukkan tidak terdapat daya hambat di media agar pada konsentrasi tetes telinga $1 \%, 3 \%$ dan $5 \%$, dengan rerata daya hambat $0,00 \mathrm{~mm}$ (Tabel 1).

\section{PEMBAHASAN}

Hasil penelitian menunjukkan adanya daya hambat (DDH) dari sediaan tetes telinga ekstrak daun Hoya carnosa konsentrasi 1\%, 3\% dan 5\% terhadap bakteri Streptococcus pyogenes, menunjukkan adanya efek bakteriostatik atau antibakteri dari senyawa aktif yang terkandung dalam daun seperti flavanoid, saponin, tannin dan alkaloid.

Mekanisme kerja flavonoid sebagai antimikroba dapat dibagi menjadi tiga yaitu menghambat sintesis asam nukleat, menghambat fungsi membran sel dan menghambat metabolisme energi. ${ }^{10}$ Mekanisme antibakteri flavonoid sebagai penghambat sintesis asam nukleat terdapat pada cincin A dan B flavonoid yang berperan penting dalam proses interkelasi atau ikatan hydrogen. Letak gugus hidroksil di posisi 2',4' atau 2',6' pada DNA bakteri dihidroksilasi pada cincin B dan 5,7 dihidroksilasi pada cincin A. ${ }^{10}$ Terganggunya proses hidroksilasi pada cincin
DNA dan RNA bakteri tersebut menyebabkan kegagalan dalam penyusunan struktur DNA serta RNA sebagai komponen penyusun asam nukleat bakteri. ${ }^{10}$ Flavonoid menghambat pembentukan energi yang dibutuhkan bakteri untuk biosintesis makromolekul pada sitokrom-C reduktase sehingga pembentukan metabolisme terhambat. ${ }^{10}$

Mekanisme tanin sebagai antibakteri berhubungan dengan kemampuannya untuk menginaktifkan adhesin sel mikroba, menginaktifkan enzim, dan menggangu transport protein pada lapisan dalam sel. ${ }^{11}$ Tanin pada dasarnya merupakan senyawa polifenol yang memiliki berat molekul besar serta terdiri dari gugus hidroksi $(-\mathrm{OH})$ dan karboksil $(-\mathrm{COOH}) .{ }^{11}$ Tanin juga mempunyai target pada polipeptida dinding sel sehingga pembentukan dinding sel menjadi kurang sempurna. Hal ini menyebabkan sel bakteri menjadi lisis karena tekanan osmotik maupun fisik sehingga sel bakteri akan mati. ${ }^{10,11}$

Mekanisme kerja saponin sebagai antibakteri adalah menyebabkan kebocoran protein dan enzim dari dalam sel bakteri. ${ }^{12}$ Saponin dapat menjadi anti bakteri karena zat aktif permukaannya mirip detergen, akibatnya saponin akan menurunkan tegangan permukaan dinding sel bakteri dan merusak permebialitas membrane, sehingga dengan rusaknya membran sel secara langsung menyebabkan kematian dari bakteri. ${ }^{12}$

Senyawa alkaloid memiliki mekanisme kerja sebagai antibakteri adalah dengan mengganggu komponen penyusun peptidoglikan yang terdapat pada dinding sel bakteri. ${ }^{13}$ Dengan lapisan dinding sel yang rusak atau tidak terbentuk secara utuh akan menyebabkan kematian sel bakteri tersebut. ${ }^{13}$ Mekanisme antibakteri lainya dari alkaloid yaitu komponen alkaloid diketahui sebagai interkelator DNA dan menghambat enzim topoisomerase sel bakteri. ${ }^{13}$

Hasil pengukuran rerata diameter daya hambat (DDH) sediaan emulsi tetes telinga Ekstrak daun "tebel-tebel" (Hoya carnosa) dengan konsentrasi 1\%, 3\% dan 5\% terhadap bakteri Staphylococcus aureus, Pseudomonas aeruginosa dan Enterobacter $s p p$, setelah dilakukan lima kali pengulangan tidak ditemukan daya hambat $(0.00 \mathrm{~mm})$ pada konsentrasi obat tetes $1 \%, 3 \%$, dan $5 \%$. Berdasarkan kriteria CLSI, rerata DDH sediaan emulsi tetes telinga ekstrak daun Hoya carnosa pada semua konsetrasi, dengan pembanding agen antibakteri Chloramphenicol, tergolong bersifat resisten (R). ${ }^{9}$ Sedangkan berdasarkan kriteria Davis WW dan Stout TR, rerata DDH sediaan emulsi tetes telinga ekstrak daun Hoya carnosa pada semua konsetrasi dikategorikan berpotensi lemah. ${ }^{14}$

Penelitian oleh Humpries RM menyatakan terdapat beberapa faktor yang mempengaruhi 
ukuran zona hambat pada uji difusi yaitu kepadatan inokulum, karena apabila inokulum terlalu padat, secara relatif ukuran DDH akan berkurang dan bakteri yang peka mungkin dilaporkan sebagai resisten. ${ }^{15}$ Waktu dari penggunaan cakram juga mempengaruhi $\mathrm{DDH}$, apabila cawan petri yang sudah disemai dengan bakteri dibiarkan dalam suhu kamar lebih waktu standar, menyebabkan terjadinya perkembangbiakan inokulum sebelum cakram digunakan yang berdampak pada turunnya $\mathrm{DDH}$, akibatnya bakteri yang peka akan terlihat resisten. ${ }^{15}$

Analisa statisik uji Anova dilakukan untuk mengetahui apakah terdapat perbedaan DDH yang bermakna pada sediaan emulsi obat tetes ekstrak daun "tebel-tebel" (Hoya carnosa) pada konsentrasi $1 \%$, 3\% dan 5\%. Berdasarkan hasil uji statistik menunjukkan tidak ada perbedaan DDH yang bermakna antara obat tetes konsentrasi $1 \%$ dan 3\% terhadap bakteri Streptococcus pyogenes, namun terdapat perbedaan DDH yang bermakna antara konsentrasi obat tetes $1 \%$ dan $5 \%$ serta $3 \%$ dan 5\% terhadap bakteri Streptococcus pyogenes. Hasil penelitian menujukkan terjadinya penurunan rerata $\mathrm{DDH}$ dari $10,20 \mathrm{~mm}$ pada konsentrasi tetes telinga $3 \%$ menjadi $7.80 \mathrm{~mm}$ pada konsentrasi tetes telinga 5\%. Hasil ini berbeda dengan penelitian Rahayu S, yang menggunakan ekstrak murni daun "tebel-tebel" atau Hoya carnosa yang mendapatkan hasil peningkatan konsentrasi ekstrak dari $80 \%$ menjadi $100 \%$ mengakibatkan kenaikan DDH yang bermakna. ${ }^{7,8}$ Penurunan DDH pada kenaikan konsentrasi ekstrak dari 3\% menjadi 5\% menunjukkan adanya penurunan stabilitas, $\mathrm{pH}$ dan polaritas dari obat tetes tersebut yang berdampak langsung terhadap efektifitas dan penetrasi dari zat aktif antibakteri pada media agar. ${ }^{16}$

Perbedaan respon hambat obat tetes ekstrak daun Hoya carnosa terhadap bakteri Gram positif dan Gram negatif disebabkan oleh karakteristik dari masing-masing bakteri tersebut. ${ }^{17}$ Sebagian besar dinding sel bakteri mengandung suatu bahan khusus unik yang disebut peptidoglikan yang terdiri dari polimer modifikasi gula-gula yang berikatan silang dengan polipeptida pendek yang berbeda dari satu spesies ke spesies yang lain. ${ }^{17}$ Bakteri Gram positif memiliki dinding sel yang lebih sederhana dengan jumlah peptidoglikan yang relatif banyak, sedangkan dinding sel bakteri Gram negatif memiliki peptidoglikan yang lebih sedikit dan secara struktur lebih kompleks. ${ }^{17}$ Dinding sel bakteri gram negatif mempunyai membran luar yang kaya akan lipid sebagai pencegah keluarnya enzim, mencegah masuknya bahan kimia ataupun senyawa aktif dari daun Hoya carnosa untuk merusak dan mematikan sel. Lapisan luar dari membran luar merupakan struktur tiga lapis tersusun atas fosfolipid, protein dan lipopolisakarida. Kondisi ini menyebabkan bakteri Gram negatif umumnya lebih resisten terhadap antibakteri dibandingkan dengan bakteri Gram positif. ${ }^{17}$

Pengujian efektifitas antibakteri dari sediaan emulsi tetes telinga ekstrak daun "tebel-tebel" (Hoya carnosa) dengan konsentrasi masing-masing $1 \%$, 3\% dan 5\% terhadap bakteri Staphylococcus aureus, Sterptococcus Pyogenes, Pseudomonas aeruginosa dan Enterobacter spp yang dilakukan secara in-vitro telah dilakukan dalam kondisi standar dan berpedoman pada Clinical and Laboratory Standards Institute (CLSI). ${ }^{15}$ Beberapa standar yang harus terpenuhi adalah konsentrasi inokulum bakteri, $\mathrm{pH}$ media agar, konsentrasi kation, suhu inkubasi, lama inkubasi dan konsentrasi antimikroba. Berdasarkan penelitian oleh Loy AH menjelaskan bahwa walaupun semua kondisi penting dalam pemeriksaan in-vitro telah distandarkan, namun tidak dapat mencerminkan kondisi yang sama dengan keadaan in-vivo tempat sebenarnya bakteri itu menginfeksi. ${ }^{18}$ Hal ini disebabkan oleh beberapa fakor seperti difusi antimikroba pada sel dan jaringan hospes, penetrasi obat tetes, terdapatnya protein serum sebagai pengikat antimikroba, imunitas hospes dan interaksi obat dengan lingkungan tempat bekerjanya obat yaitu telinga tengah.

Terdapatnya daya hambat (DDH) sediaan emulsi tetes telinga ekstrak daun "tebel-tebel" (Hoya carnosa) terhadap bakteri Steptococus pyogenes, memberikan optimisme bahwa sediaan emulsi tetes telinga ekstrak daun"tebel-tebel" (Hoya carnosa) memiliki potensi antibakteri. Resistensi antibakteri tersebut berdasarkan kriteria CLSI dengan pembanding berupa antibiotik Cholramphenicol yang merupakan sediaan bahan kimia. ${ }^{15}$ Standar ini tentunya memiliki perbedaan dengan sediaan bahan alam yang digunakan dalam penelitian ini yang belum memiliki standarisasi baku bahan alam.

Tidak adanya daya hambat pada pengujian efektifitas antibakteri dari sediaan emulsi tetes telinga ekstrak daun "tebel-tebel" (Hoya carnosa) dengan konsentrasi masing-masing 1\%, 3\% dan 5\% terhadap bakteri Staphylococcus aureus, Pseudomonas aeruginosa dan Enterobacter spp merupakan salah satu kelemahan dalam penelitian ini. Namun hal tersebut bukan berarti bahwa sediaan emulsi tetes telinga ekstrak daun Hoya carnosa tesebut tidak memiliki potensi antibakteri terhadap bakteri tersebut, sehingga perlu dilakukan penelitian lebih lanjut dengan metode perhitungan koloni kuman dan koloni kuman secara in-vivo.

Potensi bahan alam dari berupa emulsi tetes telinga ekstrak daun Hoya carnosa yang masih jauh dari pembanding kontrol positif (Chloramphenicol $1 \%$ ), sehingga perlu penyempurnaan teknik ekstraksi, pelarut, pemilihan bahan pembawa obat 
tetes dan isolasi zat aktif yang dominan untuk mendapatkan obat tetes yang lebih potensial.

\section{SIMPULAN}

Terdapat daya hambat (DDH) dari sediaan emulsi tetes telinga ekstrak daun "tebel-tebel" (Hoya carnosa) pada konsentrasi 1\%, 3\% dan 5\% terhadap bakteri Streptococcus pyogenes. Terdapat perbedaan bermakna pada diameter daya hambat (DDH) dari sediaan emulsi obat tetes telinga ekstrak daun "tebel-tebel" (Hoya carnosa) terhadap bakteri Streptococcus pyogenes pada dari konsentrasi 3\% dan 5\%. Selain itu penelitian ini juga menunjukkan terdapat perbedaan bermakna dari daya hambat obat tetes (DDH) sediaan emulsi tetes telinga ekstrak daun "tebel-tebel" (Hoya carnosa) konsentrasi $1 \%$, 3\% dan 5\% dengan Cholrampenicol 1\% terhadap bakteri Streptococcus pyogenes.

\section{KONFLIK KEPENTINGAN}

Tidak terdapat konflik kepentingan dalam penulisan laporan penelitian ini.

\section{ETIKA PENELITIAN}

Penelitian ini telah mendapat persetujuan etik dari Komisi Etik Penelitian (KEP) Fakultas Kedokteran Universitas Udayana/RSUP Sanglah, Denpasar dengan nomor 1679/UN.14.2/KEP/2017 sebelum penelitian dilaksanakan.

\section{PENDANAAN}

Peneliti bertanggung jawab terhadap pendanaan penelitian ini tanpa melibatkan pihak sponsor, beasiswa, ataupun sumber pendanaan lainnya.

\section{KONTRIBUSI PENULIS}

Seluruh penulis memiliki kontribusi yang sama dalam penulisan laporan penelitian ini baik dari penyusunan kerangka konsep, pengumpulan data, analisis data penelitian, hingga menyampaikan hasil penelitian dalam bentuk publikasi ilmiah.

\section{DAFTAR PUSTAKA}

1. Verhoeff M, van der Veen EL, Rovers MM, Sanders EA, Schilder AG. Chronic suppurative otitis media: a review. Int J Pediatr Otorhinolaryngol. 2006;70(1):1-12.
2. Aduda DS, Macharia IM, Mugwe P, Oburra H, Farragher B, Brabin B, et al. Bacteriology of chronic suppurative otitis media (CSOM) in children in Garissa district, Kenya: a point prevalence study. Int J Pediatr Otorhinolaryngol. 2013;77(7):1107-1111.

3. Mittal R, Lisi CV, Gerring R, Mittal J, Mathee K, Narasimhan G, et al. Current concepts in the pathogenesis and treatment of chronic suppurative otitis media. J Med Microbiol. 2015;64(10):1103-1116

4. Beaugard ME, Asakuma S, Snow JB Jr. Comparative ototoxicity of chloramphenicol and kanamycin with ethacrynic acid. Arch Otolaryngol. 1981;107(2):104-109.

5. Bron AJ, Leber G, Rizk SN, Baig H, Elkington AR, Kirkby GR, et al. Ofloxacin compared with chloramphenicol in the management of external ocular infection. Br J Ophthalmol. 1991;75(11):675-679.

6. Kooti W, Farokhipour M, Asadzadeh Z, Ashtary-Larky D, Asadi-Samani M. The role of medicinal plants in the treatment of diabetes: a systematic review. Electron Physician. 2016;8(1):1832-1842.

7. Rahayu S, Fakhrurrozi Y, Putra HF. Hoya species of Belitung Island, Indonesia, utilization and conservation. Biodiversitas. 2018;19(2):369-376.

8. Rahayu S, Rodda M. Hoya narcissiflora, a new species from Borneo. Reinwardtia. 2017;16(1):10-16.

9. Kassim A, Omuse G, Premii Z, Revathi G. Comparison of Clinical Laboratory Standards Institute and European Committee on Antimicrobial Susceptibility Testing guidelines for the interpretation of antibiotic susceptibility at a University teaching hospital in Nairobi, Kenya: a cross-sectional study. Ann Clin Microbiol Antimicrob. 2016;15:21.

10. Kumar S, Pandey AK. Chemistry and biological activities of flavonoids: an overview. ScientificWorldJournal. 2013;2013:162750. Published 2013 Dec 29.

11. Chung KT, Wong TY, Wei CI, Huang YW, Lin Y. Tannins and human health: a review. Crit Rev Food Sci Nutr. 1998;38(6):421-464.

12. Podolak I, Galanty A, Sobolewska D. Saponins as cytotoxic agents: a review. Phytochem Rev. 2010;9(3):425-474.

13. Ziegler J, Facchini PJ. Alkaloid biosynthesis: metabolism and trafficking. Annu Rev Plant Biol. 2008;59:735-769.

14. Davis WW, Stout TR. Disc plate method of microbiological antibiotic assay. II. Novel procedure offering improved accuracy. Appl Microbiol. 1971;22(4):666-670.

15. Humphries RM, Ambler J, Mitchell SL, Castanheira M, Dingle T, Hindler JA, et al. CLSI Methods Development and Standardization Working Group Best Practices for Evaluation of Antimicrobial Susceptibility Tests. J Clin Microbiol. 2018;56(4):e01934-17.

16. Howard CA. Pharmaceutical Dosage Forms and Drug Delivery. Dalam: Lippincott Williams and Wilkins. Textbook of Pharmacy. Philadelphia. University of Toledo College of Pharmacy: Walter Kluer Bussines Systems. 2011: p.184-722.

17. Anjum MF, Zankari E, Hasman H. Molecular Methods for Detection of Antimicrobial Resistance. Microbiol Spectr. 2017;5(6):10.1128/microbiolspec.ARBA-0011-2017.

18. Loy AH, Tan AL, Lu PK. Microbiology of chronic suppurative otitis media in Singapore. Singapore Med J. 2002;43(6):296-299.

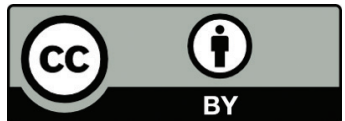

This work is licensed under a Creative Commons Attribution 